\section{Magzati varicellabetegség}

\section{Tisztelt Szerkesztőség!}

Egy várandós 2014. december 15-én az alábbi szakvéleménnyel kereste fel az általam vezetett genetikai tanácsadót, amit az egyik fơvárosi intézmény genetikai tanácsadója adott ki. A várandósnak - elmondása szerint - a terhesség megszakítását ajánlották, pedig a 40 éves nő nagyon szeretett volna szülni.

„Jelenleg 9 hetes terhes. Körülbelül 2 hete jelentkeztek varicellás klinikai panaszai. Az elvégzett klinikai szerológia megerősítette a terhesség korai szakában (7. hét körül) lezajlott friss varicellafertőzés tényét.

A friss varicellafertőzés miatt a teratoló giai ártalom kockázata emelkedett. A lehetséges kedvezőtlen következményekről (idegrendszeri, kardiális stb.) a házaspárt részletesen felvilágosítottuk. Nem létezik azzal kapcsolatos 100\%-os diagnosztika, hogy a terhesség során az embrió érintettsége milyen fokú. A lehetséges szerológiai vizsgálatról, a magzatvízvétel során nyert minta vizsgálatáról felvilágosítottuk.

Tekintettel a fentiekre, a terhesség megszakítása, a terhességi kort is figyelembe véve, genetikai szempontból is megindokolható.

A házaspár a fentiek alapján dönthet a terhesség sorsáról. Amennyiben a terhesség megszakítása mellett döntenek, úgy a kezelőorvos felkeresése minél hamarabb indokolt.

A terhesség továbbviselése esetén genetikai kontroll javasolt a 12. hét körül.

A gravida és férje a mindenre kiterjedó részletes felvilágosítás után aláírásával igazolja, hogy a tanácsadáson elhangzottakat megértette, a tanácsadó javaslatát tudomásul vette. További kérdése nincs.

2015. 02.06.

A terhes aláirása.”

Korábban PhD-s munkatársammal összefoglaltuk a várandósok varicellabetegségével kapcsolatos ismereteket a nemzetközi szakirodalom és saját eredményeink alapján [1], de úgy tünik, ezeket nem veszik figyelembe a genetikai tanácsadással foglalkozó szakemberek, és emiatt indokolatlanul kerülhet sor terhességek megszakítására. Ezért érzem fontosnak újra szóba hozni a fontosabb tudnivalókat.

A varicella-zoster vírus egyike a 8 herpeszvírusnak a Herpesviridae családon belül. A varicellában szenvedő betegek nagyon ragályosak, a velük érintkezők 61-100\%-a megfertőződik.

1. Az anya varicellamegbetegedése valójában nem fejlődési rendellenességet, hanem magzati betegséget idéz elő. Erre utal a magzati varicellabetegség (MVB) kritikus időszaka, ami a 10. és 21 . gesztációs hét közé esik (amikor az utolsó havi vérzés első napjától számítjuk a várandósság idejét). Ha a magzati életkort a fogamzástól számítjuk, akkor ez az időszak a 8. és 19. hetet öleli fel. A várandósság utolsó heteiben előforduló varicellabetegség miatt az újszülött esetleg a varicellabetegség tüneteivel jöhet a világra, ilyenkor szokás congenitalis (helyesebb lenne connatalis) varicelláról beszélni.

A minket felkereső várandósban a varicellabetegség viraemiás időszaka e kritikus időszak előtt fordult elő, a mérvadónak tartott prospektív vizsgálatok eredményei szerint ilyenkor magzati ártalommal nem kell számolni.

2. Az MVB jellemző „tünetei” valójában nem fejlődési rendellenességek, hanem a bőr- és nyálkahártya-gyulladás elsődleges vagy másodlagos következményei. Az elsődleges tünetek közé sorolható a bôr gyulladását követő hegesedés és a fülkagyló elváltozásai (microtia és növedékek, amik a füllkagyló bőrének károsodásával kapcsolatosak). A másodlagos tünetek közé elsősorban a csontok fejlódési zavara sorolható, mivel a bőrhegek növekedést visszafogó és torzító hatása miatt elsősorban a gyorsan növekvő csöves csontok károsodhatnak. Az utóbbiak súlyosabb megnyilvánulása a várandósság 20 . hetében végzett ultrahangvizsgálattal esetleg kórismézhető. A bőr mellett a nyálkahártyák gyulladása is kialakulhat, beleértve a szem kötőhártyáját is. (Az utóbbi ráterjedve a corneára, majd innen a szem mélyebb rétegeire, az ezt követő hegesedés minden funkcionális következményével.) Végül a kórokozó nagyon ritkán a bőrön (külső hallójáraton, majd a középfülön át) vagy a szemen áthatolva az agyszöveteket is elérheti, és az ott okozott gyulladás agyi hegesedést, epilepsziás rohamot, esetleg értelmi fogyatékosságot idézhet elo".

Genetikai tanácsadónk 1973 és 1998 közötti anyagában 67 várandós azért jelentkezett, mert már meglevő, idősebb gyermekük varicellabetegségben szenvedett aktuális terhességük alatt, vagy ritkábban azért, mert más, varicellabetegségben szenvedő beteggel érintkeztek. Féltek e lehetséges fertőzések magzati ártalmasságától, noha ók maguk korábban átestek varicellabetegségen. A 67 édesanya közül 65-ben sikerült tisztáznunk szülésük kime- netelét, MVB gyermekükben nem fordult elő.

A minket felkereső várandósok közül 24 maga szenvedett varicellabetegségben aktuális terhessége idején. A kapott felvilágosítás és tanácsadásunk ellenére 4 nő megszakíttatta a terhességét. A fennmaradó 20 várandós közül 19-nél sikerült szülésük orvosi dokumentációját megismerni, egyetlen csecsemóben sem fordult elö MVB! A saját varicellabetegség miatt jelentkező, tanácsot kérő várandósok 5 évenkénti gyakorisága számottevő (26-szoros!) növekedést mutatott a vizsgált időszakban.

Anyagunkban szereplő 10 gyermeket betegségük miatt hozták el szülei, akiknél édesanyjuk várandósság alatti varicellabetegsége alapján felállítható volt az MVB diagnózisa az említett jellegzetes tünetek alapján.

3. Az anya varicellamegbetegedésekor az MVB 1-2\%-os kockázatával számolnak. Az lehet a magyarázata ennek az alacsony kockázatnak, hogy az anyai varicellamegbetegedéseknek csak 20\%-ában jut át a lepényen a kórokozó a magzatba, és ilyenkor sem mindig jut el a vírus „célszöveteihez”: a bőrhöz és a nyálkahártyákhoz.

A magyar Fejlődési Rendellenességek Eset-Kontroll Felügyelete (korábbi neve Kóroki Monitor) anyagában 1980 és 1996 között 22843 rendellenes eset és 38151 nem rendellenes kontroll szerepel. A rendellenes esetú édesanyák között 31 esetben jelentettek varicellabetegséget, ez $0,14 \%$-os gyakoriságot jelent. A kontrollok között 56 édesanyjának varicellás betegsége vált ismertté, ami $0,15 \%$-os születéskori prevalenciának felel meg. A két gyakoriság között minimális a különbség. Említést érdemel, hogy a vizsgált időszakban a varicellás várandósok összgyakorisága az 1980 és 1984 közötti évek 0,10\%-os értékéről az 1990-1996 közötti években 0,19\%-ra, tehát közel kétszeresére emelkedett.

Az említett 31 eset közül 28-nak izolált és 3-nak multiplex rendellenessége volt. A 28 izolált rendellenesség közül legfeljebb egy microtiás gyermek lehetett kapcsolatban az anya varicellabetegségével a várandósság 4. hónapjában. A többi rendellenesség - elemzésünk szerint - véletlen egybeesésnek ítélhetó, a rendellenességek jellege, illetve az anya varicellabetegsége nem esett egybe az adott rendellenesség kritikus kialakulási időszakával. A 3 multiplex rendellenességű eset közül kettóben valószínúsíthető volt az MVB. Az egyik újszülöttben microtia és vastagbél-elzáródás fordult elő a várandósság 3. hónapjában történt varicellabetegséget követően. A másik újszülöttnek microphthalmiája és 
microtiája volt, a várandósnak az 5 . hónapban volt varicellabetegsége. A harmadik esetben az anya várandósságának 2 . hónapjában kapta meg a varicellabetegséget, és csecsemőjénél congenitalis hydrocephalia, kétoldali külső hallójárat-elzáródás (a fülkagyló épsége mellett) és komplex cardiovascularis rendellenessége (ventricularis és atrialis septumdefektus) volt a diagnózis. Ezek a rendellenességek nem jellemzőek az MVB-re.

4. A magyar törvények akkor engedik meg az orvosi indikáció alapján végzett terhességmegszakítást a 12 . gesztációs hétig, ha a magzat súlyos ártalmának a kockázata $10 \%$ vagy magasabb. Így a várandósság alatt varicellás nők csak válsághelyzetükre hivatkozva szakíttathatják meg terhességüket a 12. gesztációs hétig.

Mindezekről tájékoztattam a tanácsadásért hozzám forduló várandóst, aki ezt követően a várandósságának megtartása mellett döntött.
Hozzászólásomnak 3 célja van:

Egyfelól fontos felhívni arra a figyelmet, hogy a varicellamegbetegedések életkor szerinti előfordulása jelentős változást mutatott az elmúlt évtizedekben. Korábban lényegében minden kislány átesett e betegségen gyermekkorában, ezért várandós időszakuk alatt nem kellett varicellamegbetegedéstől tartaniuk. Ezzel szemben az utóbbi idóben egyre többen nem kapják meg ezt a fertőző betegséget gyermekkorukban, ezért ki vannak téve a fertőzésveszélynek a várandósságuk alatt is.

Másfelől, éppen a bekövetkező demográfiai változás miatt, nagyon fontos tudatosítani, hogy rendelkezésre áll a varicella elleni oltás (Varilix, GSK) és ezt minden olyan, várandósságra vállalkozó nőnek meg kellene kapnia, aki korábban nem esett át ezen a fertőző betegségen. Ellenőrző szerológiai vizsgálataink tanúsága szerint a családtervező nók és várandósok ilyen jellegü anamnesztikus információja megbízhatónak tekinthető.
Végül nem szabad összekeverni a genetikai eredetű és a várandósság alatt külső okokra visszavezethető fejlődési zavarokat, mivel eredetük és ismétlődési kockázatuk alapvetően különbözik. Éppen ezért megkérdőjelezhetô, hogy a teratogén és fetopatogén (magzati betegséget okozó) ártalmakkal kapcsolatos tanácsadás a genetikai tanácsadókra tartozik-e, amelyet genetikai képzettségű szakemberek végeznek.

Dr. Czeizel Endre „Genetikai Ártalmak Társadalmi Megelőzése" Alapítvány e-mail: czeizel@interware.hu

\section{Irodalom}

[1] Gidai, J., Bács, É., Czeizel, E.: Fetal varicella syndrome. [Magzati varicellabetegség.] Orv. Hetil., 2007, 148(29), 1373-1379.

Az Orvosi Hetilap egyes számai megvásárolhatók a Mediprint Orvosi Könyvesboltban.

Cím: Budapest V., Múzeum krt. 17. - Telefon: 317-4948 


\section{Diabetológia}

\section{A statinok diabetogén hatásának patogenezise és kezelése: mi ebben az adiponektin és a koenzim $Q_{10}$ szerepe? (Pathogenesis and management of the diabetogenic effect of statins: a role for adiponectin and coenzyme $\mathbf{Q}_{10}$ ?) Chan, D. C., Pang, J., Watts, G. F. (G. F. Watts, Cardiometabolic Medicine, Royal Perth Hospital, Perth, Western Australia, Ausztrália; e-mail: gerard.watts@uwa.edu.au): Curr. Atheroscler. Rep., 2015, 17(1), 472 .}

Egyre több adat jelenik meg azzal kapcsolatban, hogy a statinkezelés során megemelkedik a diabetes kialakulásának kockázata. Ezt több tényező befolyásolhatja, mint például az életkor, az egyén diabeteskockázata és a statin típusa, valamint adagja is. Különböző mechanizmusok merültek fel a statinok diabetogén hatásával kapcsolatban, amelyben szerepet játszhatnak az adiponektin és a koenzim $\mathrm{Q}_{10}$ $\left(\mathrm{CoQ}_{10}\right)$ szintjeinek változásai is.

A statinkezelés csökkentheti a zsírszövet által termelt adiponektin koncentrációját, amelynek hatására csökken a szabad zsírsav oxidációja és megnő a glükóz szintézise is. Ennek hatására csökken az inzulinszenzitivitás mértéke. Egymásnak ellentmondó eredmények jelentek meg azonban azzal kapcsolatban, hogy van-e különbség a lipofil statinok (simvastatin, atorvastatin) és a hidrofil statinok (pravastatin, rosuvastatin, pitavastatin) adiponektinre és ezzel az inzulinérzékenységre, végső soron a diabetes kialakulásának kockázatára gyakorolt hatásában.

A mitokondrium múköódésében fontos szerepet játszó $\mathrm{CoQ}_{10}$ koncentrációja csökken a statinterápia során. Ennek következtében mérséklődik az ATP termelése és ezzel az inzulin szekréciója is. Klinikai vizsgálatok azonban még nem jelentek meg azzal kapcsolatban, hogy van-e direkt öszszefüggés a statinkezelés $\mathrm{CoQ}_{10}$ szintjét csökkentő hatása és a diabetes kialakulásának kockázata között.

Ábel Tatjána dr

\section{Gasztroenterológia}

Az epehólyag: ritka és gyakori betegségek szokatlan megjelenési formái (The gallbladder: uncommon gallbladder conditions and unusual presentations of the common gallbladder pathological processes) Revzin, M. V., Scoutt, L., Smitaman, E., et al. (Department of Radiology, Yale School of Medicine, 20 York St, New Haven, CT 06510, Amerikai Egyesült Államok; e-mail: margarita.revzin@yale.edu): Abdom. Imaging, 2015, 40(2), 385-399.

$\mathrm{Az}$ epehólyag betegségeinek spektruma széles. Az Amerikai Egyesült Államokban 20 millióra becsülik az epehólyag-betegségben szenvedők számát. Revzin és mtsai közleménye a ritka kórképekkel és gyakori betegségek szokatlan megnyilvánulásaival foglalkozik.

A szerzők leírják az egészséges epehólyag hosszát, szélességét, térfogatát, falvastagságát és helyzetét. Írnak a veleszületett rendellenességekről, mint például a multiszeptált, a frígiai sapka alakú, a kettőzött és ectopiás epehólyag. Gyulladásos és kővel összefüggó betegségek az epehólyagfal lymphangiomája, a porcelán epehólyag, az adenomyomatosis, a xanthogranulomatosus, emphysematosus, gangraenás és haemorrhagiás cholecystitis, a perforáció, az epekőileus, a Bouveret- és Mirizzi-szindróma. A daganatos betegségekról (carcinoma, metasztázis, sarcoma, lymphoma, melanoma és neurofibroma) is olvashatunk. Néhány kiemelt megállapításuk:

Az epehólyag szokásos helye a has jobb felső kvadránsa, de elhelyezkedhet akár a bal alsó kvadránsban is. Előfordulhat intrahepaticus epehólyag is, a máj az epehólyagot teljesen körülveszi. A porcelán epehólyag (porcelain gallbladder) a fal meszesedése, amely röntgennel, ultrahanggal és CT-vel jól látható. Igen gyakran társul hozzá epehólyag-carcinoma. Az emphysemás cholecystitis az egyetlen, epekővel öszszefüggő betegség, amely férfiakban gyakoribb. (Az epekőbetegség, az akut és krónikus cholecystitis, az epekőileus, az epehólyag-carcinoma nókben gyakoribbak.) A mésztej epét (limy bile, Kalkmilchgalle), amely sok kalciumsót tartalmaz és natív röntgenképen jól látható, a szerzők nem említik. A közleményben számos röntgen-, ultrahang-, CT- és MR-felvétel látható. A szerzók csaknem száz szakcikkre hivatkoznak.

Gáspárdy Géza dr.

\section{Kardiológia}

A koenzim $Q_{10}$ hatása a morbiditásra és a mortalitásra idült szívelégtelenségben: Q-SYMBIO vizsgálat (The effect of coenzyme $Q_{10}$ on morbidity and mortality in chronic heart failure: results from Q-SYMBIO: a randomized double-blind trial) Mortensen, S. A., Rosenfeldt, F., Kumar, A., et al. ([Dr. Mortensen] Department of Cardiology, Heart Centre, Copenhagen University Hospital, Copenhagen, Dánia; e-mail: doctormortensen@gmail.com): JACC Heart Fail., 2014, 2(6), 641-649.

A szívelégtelenség (HF) optimális terápiás tervének felállítása sok buktatót rejt: a HF hátterében számos ok állhat, de úgy tûnik, hogy az állapot kialakulásához nagyban hozzájárulhat a bioenergetikai múködészavar is, amely a szívizomsejtek energiahiányához vezet. A koenzim $\mathrm{Q}_{10}\left(\mathrm{CoQ}_{10}\right)$ erőteljes hatású, lipidoldékony antioxidáns, és egyben az ATP-szintézis központi redoxkomponense.

HF-ben szenvedő betegeknél a $\mathrm{CoQ}_{10^{-}}$ tartalom myocardialis csökkenését igazolták, amely összefüggést mutat a tünetek súlyosságával és a kamrai funkciózavar mértékével. Az alacsony plazma- $\mathrm{CoQ}_{10^{-}}$ szint a halálozás független prediktora HF-ben.

A HF terápiájában alkalmazott $\mathrm{CoQ}_{10^{-}}$ zel kapcsolatos véletlen besorolásos, kontrollcsoportos vizsgálatok (RCT) többnyire pozitív hatást igazoltak a bal kamrai ejekciós frakció (EF) tekintetében, emellett a NYHA szerinti funkcionális státus is javult.

A SYMBIO prospektív, véletlen besorolásos, kettős vak, placebokontrollos, multicentrikus vizsgálatban a $\mathrm{CoQ}_{10}$-et a szokványos HF-kezelés kiegészítéseként alkalmazták.

A vizsgálat résztvevőit 17 európai, ázsiai és ausztráliai egészségügyi centrum betegei közül toborozták 2003 és 2010 között.

Összesen 420 beteget soroltak be: 202 beteg aktív $\mathrm{CoQ}_{10}$-kezelésre, 218 beteg a placebocsoportba került. A vizsgálat során az aktív terápiás csoportban naponta $3 \times 100 \mathrm{mg} \mathrm{CoQ}_{10}$-et alkalmaztak a szérumszint szignifikáns növelése céljából. Az elsődleges végpontot (MACE) 86 beteg érte el, 60 beteg meghalt.

A SYMBIO az első RCT, amelyben a mintanagyság, a $C_{0} Q_{10}$ adagja és a követés időtartama lehetővé tette annak felmérését, hogy a $\mathrm{CoQ}_{10}$ hatásosan csökkenti-e a HF morbiditását és mortalitását.

A CoQ 10 -pótlás szignifikánsan, $43 \%$-kal csökkentette a MACE előfordulását és a cardiovascularis mortalitást, illetve $42 \%$-kal csökkentette az összesített mortalitást. $\mathrm{CoQ}_{10}$-szedés mellett 2 év elteltével lényegesen enyhültek a betegek tünetei (a NYHA 
funkcionális osztályozás alapján). $\mathrm{A} \mathrm{CoQ}_{10^{-}}$ csoportban a 16. héten nem szignifikáns csökkenést észleltek az NT-proBNP-szintekben. A 106. hétre az NT-proBNP-koncentráció mindkét vizsgálati csoportban kevesebb, mint felére csökkent a kiindulási értékhez képest.

Összefoglalva: A Q-SYMBIO vizsgálat eredményei azt jelzik, hogy a közepesen súlyos vagy súlyos szívelégtelenség szokványos kezelésének $\mathrm{CoQ}_{10}$-zel való kiegészítése biztonságos és jól tolerálható módszer, amely a tünetek enyhülésével és a jelentős cardiovascularis események számának csökkenésével társul.

Fischer Tamás dr.

\section{Radiológia}

Az MRI és az ultrahangfúziós képalkotás a praenatalis kórismében (MRI and ultrasound fusion imaging for prenatal diagnosis) Salomon, L. J., Bernard, J. P., Millischer, A. E., et al. (Service de Gynécologie Obstétrique, Hôpital Necker Enfants Malades, Paris,

Franciaország): Am. J. Obstet.

Gynecol., 2013, 209(2), 148.el-e9.

A szerzők 24 terhest vizsgáltak a terhesség 24-35. hetében a mágneses rezonancia és a dinamikus ultrahang-ábrázolás fúziójával.
A vizsgálatok átlagos tartama $10 \pm 5$ perc volt. Jelentős magzatmozgás miatt 15 esetben a vizsgálatot meg kellett ismételni. A standard dinamikus ultrahangvizsgálat az 1 . és 2 . trimeszterben eredményes diagnosztikus módszer a súlyos praenatalis abnormitások többségében. A praenatalis MR-nek a kontrasztfeloldó képessége jobb és kevésbé korlátozza a magzat kedvezőtlen elhelyezkedése, az előrehaladott terhességi kor, az ikerterhesség, az anyai obesitas. A két módszer fúziója bármelyik hátrányt áthidalja.

Jakobovits Antal dr.

\section{A rendezvények és kongresszusok híranyagának leadása}

a lap megjelenése előtt legalább 40 nappal lehetséges, a 6 hetes nyomdai átfutás miatt. Kérjük megrendelőink szíves megértését.

A híranyagokat a következő címre kérjük: Orvosi Hetilap titkársága: Budai.Edit@akkrt.hu Akadémiai Kiadó Zrt. 


\section{Magyarország versenyképessége a klinikai vizsgálatokban}

A Nemzeti Kutatási, Fejlesztési és Innovációs Hivatal elnöke, prof. dr. Pálinkás József védnökségével, az Innovatív Gyógyszergyártók Egyesülete az Európai Gyógyszergyártók és Egyesületek Szövetségével együttmúködésben 2015. március 4-én tartotta meg a „Klinikai Kutatások Konferencia 2015: Az egészségügy mint a legnagyobb magyar tudományos intézmény" című rendezvényét a Magyar Tudományos Akadémia Székházában.

A konferencia előadói: prof. dr. Pálinkás József elnök (Nemzeti Kutatási, Fejlesztési és Innovációs Hivatal), dr. Zombor Gábor egészségügyért felelős államtitkár (Emberi Erőforrások Minisztériuma), $d r$. Richard Bergström vezérigazgató (Európai Gyógyszergyártók és Egyesületek Szövetsége), dr. Nathalie Seigneuret kiemelt tudományos projektvezető (Innovative Medicines Initiative), dr. Molnár Mária Judit rektorhelyettes (Semmelweis Egyetem), dr. Jakab Zoltán elnök (Innovatív Gyógyszergyártók Egyesülete), dr. Pozsgai Csilla főigazgató (Országos Gyógyszerészeti és Élelmezésegészségügyi Intézet.), dr. Kuluncsis Zéno klinikai kutatásvezető (Innovatív Gyógyszergyártók Egyesülete).

A kerekasztal-beszélgetés résztvevői: $d r$ Antal Gabriella föigazgató (Magyar Kórházszövetség elnöksége), dr. Poór Gyula korábbi elnök (Magyar Orvostársaságok és Egyesületek Szövetsége), dr. Veres Lászlo elnök (Magyarországi Klinikai Vizsgálatvezetők Társasága), dr. Pogány Gábor elnök (Nemzeti Betegfórum), Koltai Tünde elnök (Betegszervezetek Magyarországi Szövetsége).

„A rendezvény célja a klinikai kutatásokon keresztül megjelenő tudományosszakmai fejlődés és gazdasági befektetés jelentőségének bemutatása egészségügyi, gazdasági, innovációs és politikai szemszögból, a tudományos eredmények felhasználásának ösztönzése, valamint $\mathrm{Ma}$ gyarország korábban megszerzett kedvezó versenyhelyzetének megőrzése és erősítése a gyógyszeripari innovációban és a klinikai kutatásokért folyó versenyben."

Magyarországon viszonylag kevés olyan ágazat van, amely meghatározó szerepet játszik a gazdaság dinamizálásában, ezek között viszont kiemelkedő jelentőségű a gyógyszeripar.

A hazánkban végzett innovatív gyógyszerfejlesztési klinikai vizsgálatok nemzetközi viszonyításban is élen járnak a vizsgálóhelyek és a felkészült szakemberek biztosításában, így az új gyógyszerekhez kapcsolódó klinikai kutatások évente 86-95 milliárd forintnyi értéket hoznak a magyar nemzetgazdaságnak, amelynek jelentős része közvetlen és közvetett foglalkoztatással, valamint az ebből származó jövedelmekből tevődnek össze az egészségügyben. Lényeges, hogy emellett jelentôs a munkahelymegtartó, az orvosi életpályát és tudományos elismertséget garantáló hatása. Ez mintegy 34-38 milliárd $\mathrm{Ft}$ adóbevételt jelent a központi költségvetésnek a különböző adónemeken, kiemelten a személyi jövedelemadón és a társasági nyereségadón keresztül.

A jelentős gazdasági és egészségügyi hatással bíró klinikai vizsgálatokért kiélezett verseny zajlik világszerte. A legtöbb klinikai vizsgálatot végző európai ország rangsorában Magyarország jelenleg az első tíz között van, megelőzve Lengyelországot és Csehországot. Az élen Németország, az Egyesült Királyság és Franciaország áll. Magyarország kedvezó pozíciójának megtartásához megkerülhetetlen a befektetőés kutatásbarát környezet kialakítása és fejlesztése, ami jótékonyan befolyásolhatja a hazánkat érintő további befektetôii döntéseket is.

A klinikai vizsgálatok nemzetközi piaca az utóbbi években kismértékben, de szûkült, és a vizsgálóhelyek az Európai Unión és az Amerikai Egyesült Államokon kívülre, egyre keletebbre tolódtak a gyorsabb betegbeválasztás és a résztvevők nagyobb motiváltsága miatt.

A konferencián előadások hangzottak el a hazai klinikai kutatások jelentőségérôl a gazdaságban és az egészségügyi ellátásban, illetve e kutatások előnyeiről az intézmények, vizsgálóteamek és a betegek vonatkozásában. Magyarországon megvan a megfelelő tapasztalat és a tudományos minőség ahhoz, hogy az ország megtarthassa a klinikai vizsgálatok terén kiharcolt pozícióját, illetve tovább javíthassa azt egyedülálló, értéknek számító, centralizált betegadatbázisának bevonásával. Egyszerú szabályozó eszközökkel és EU-s források felhasználásával a vizsgálócentrumok számát lehet növelni, a betegadatbázisok elérhetôségét kutatási célokra lehet fejleszteni, vizsgálati helyiségek kialakítása és tréningek szervezése, illetve a jogi szakemberek számítógépes hozzáférése valósulhat meg.

Az innovatív gyógyszerekkel kapcsolatos kutatási ráfordítások közel felét költik új onkológiai hatóanyagok kifejlesztésére, és az összes vizsgálat negyede irányul azok tesztelésére. A gyógyszeripari innovációban kiemelt területek a központi idegrendszeri, szív- és érrendszeri, metabolikus és táplálkozási tanulmányok, a légzőszervi kórképek, bőrgyógyászat, a reumatológia és mozgásszervi klinikai vizsgálatok is.
A klinikai kipróbálások hozzájárulhatnak a jelentős költséggel járó innovatív terápiák hazai alkalmazásához. A betegek számára ingyenesen rendelkezésre bocsátott gyógyszerek a költségvetés egészségügyi kiadásait nagymértékben csökkentik. A betegek szempontjából kedvező, hogy évente közel 20 ezren juthatnak hozzá kísérleti gyógyszerekhez, és ezek az új készítmények egyre javuló életminőséget, sőt teljes tünetmentességet hozhatnak a krónikus betegségekben szenvedőknek.

Kalkulációk szerint Magyarországon a klinikai vizsgálatok nemzetgazdasági értéke tovább növelhetó, és így mintegy évi 18-28 milliárd forint többletbevétel érhető el, ami a következő 10 évben várhatóan szinten tartható, ezért ösztönözni kell a gyógyszergyártók versenyelőnyt biztosító kutatásfejlesztési célú befektetéseit.

Mivel az Európai Gyógyszerügynökség (EMA) 2014. június 16-án hatályba lépett új szabályzata következtében 2016-ig fokozatosan megszúnik a magyarországi engedélyezési folyamatok szakszerü és átlátható múködéséből származó versenyelőny egy része, a versenyelőny megtartásához a következő aktív lépések szükségesek:

- a megfelelő jogi környezet kialakítása,

- transzparens és kiszámítható pénzügyi környezet megteremtése,

- egy központosított, naprakész adatbázisrendszer felállítása és elérhetőségének megteremtése,

- a klinikai kutatási adminisztráció egyablakossá tétele az egyes intézmények szintjén is,

- és végül, de nem utolsósorban a klinikai kutatáshoz szükséges szakmai kompetenciák beépítése az orvosi és az egészségügyi szakdolgozói életpályamodellekbe, kiegészítve a képzett munkaeró itthon tartásának és hazatérésének keretrendszerét.

E feladatok megvalósítása döntő jelentőségû́ a nemzetgazdaság szempontjából is

Blázovics Anna dr.

\section{Képzési és továbblépzési modell az egészségügyi alapellátásban. Az Alapellátási Szabadegyetem fennállásának negyedszázados jubileuma}

\section{Györ, Városháza, 2015. február 7.}

Az Egészséges Nemzedékért Alapítvány 25 éve folyamatosan szervez szakmai tudományos továbbképzést családorvosoknak 
Győr város önkormányzata és az orvostudományi egyetemek családorvosi tanszékeinek és intézeteinek koordinálásában, 2007 óta a Semmelweis Egyetem ÁOK Családorvostani Tanszékével közösen. A szakmai tudományos rendezvények Győrött a városházán minden hónap 2. szombatján - a nyári szünetet leszámítva -, évente 10 alkalommal kerülnek megrendezésre. A továbbképzések legfontosabb célja: a háziorvosoknak naprakész információk biztosítása. A résztvevők a diagnosztika és terápia újdonságairól, az egészségügy gazdaságiközgazdasági, jogi, etikai kérdéseiről, valamint az informatikával és egészségbiztosí tással kapcsolatos tudnivalókról kaphatnak részletes ismeretanyagot.

A családorvosok számára komoly rangot jelent - amely egyben az alapellátás minőségi munkájának elismerése is -, hogy a kollégák üléselnökként és előadóként vesznek részt a rendezvényeken, és vitavezetóként is aktív szerepet vállalnak. Az Alapellátási Szabadegyetem rendezvényein, a továbbképzéseken a jelentkezők regisztrációs díj nélkül vehetnek részt. A háziorvosokon kívül mind több kórházi orvos, ÁNTSZ-szakember és egészségügyi szakdolgozó csatlakozik a résztvevókhöz, akik számára az előakkreditált tudományos továbbképzések 16 kreditpontot biztosítanak.

A negyedszázados jubileum, az Alapellátási Szabadegyetem XXV. évfolyamának első, tanévnyitó rendezvénye volt a február 7-ei, sorrendben a 215. szakmai tudományos szimpózium. Visszatekintve az előző 25 évre, vagyis az eddigi folyamatosan szervezett 214 rendezvényre, egyegy tudományos üléshez kapcsolódóan átlagosan 100-120 fó résztvevốt számolunk, úgy az elmúlt negyedszázad során közel 30 ezer kolléga részvételét regisztrálhattuk. Mivel a továbbképzéseken a részvétel díjmentes volt, a megtakarítás a kollégák számára százmillió forintot is meghaladhat.

A jubileumi rendezvényt Schmidt Péter professzor nyitotta meg, aki visszatekintésében az elmúlt negyedszázad eredményeirôl számolt be, és külön kitért a régióból, illetve az ország számos megyéjéből érkezett kollégák aktív részvételére.

A jubileumi tudományos ülés keretében elsőként Feller Gábor dr. a családorvosi ellátás és a pszichiátriai szakterület kapcsolatáról adott tájékoztatót. Kiemelte, hogy az elmúlt időszakban a pszichés-pszichoszomatikus megbetegedések aránya jelentősen megnőtt, ezen túlmenően aggasztó jelenség, hogy hétvégenként mind több fiatal kerül a diszkókból és egyéb szórakozóhe- lyekről súlyos drogfogyasztás következményeként kórházi osztályra. A fiatalok aránya az elmúlt 1-2 évben 25-30\%-kal emelkedett, a súlyosabb esetek, sajnos, az egyre fiatalabb korosztályból kerülnek ki, nem ritka a 15-16 éves rendszeres drogfogyasztó sem. Előadásában kiemelten hívta fel a figyelmet a drogprevenció fontosságára.

Menyhárt Miklós dr. hazai és nemzetközi tapasztalatok alapján számolt be az Alzheimer-kórban szenvedő betegek ellátásáról, gondozásáról és terápiájáról. Franciaországi gyakorlati példán keresztül ismertette, hogy számos esetben nem is az anyagiak, hanem a korszerú gondozási munka, a folyamatos nyomon követés és a családtagok aktív bevonása segíthet a mind nagyobb számú, fenti diagnózissal gondozott beteg ellátásában. Magyarországi példát említve sikerként számolt be a havi rendszerességgel múködő, győri kezdeményezésű Alzheimer Café Továbbképzési Központról, amely szakemberek és laikusok közös összefogásának eredménye. Múködésébe a szervezők folyamatosan bevonják a Pécsi Tudományegyetem ÁOK Családorvostani Intézetének Alzheimer Kutatócsoportját.

Kovács Tibor $d r$. a pulmonológiai gondozás fontosságáról számolt be, kitért a megemelkedett pollenallergiás betegszámra, és felhívta a figyelmet az évszakhoz köthetố tünetek egyre gyakoribb előfordulására. A környezetszennyezés is nagyon sokat árthat ezeknek a betegeknek, viszont kellő odafigyeléssel és a betegek tájékoztatásával mind a táppénzes napok száma, mind pedig az egészséges években mérhető gyógyulás fontos indikátor lehet. A gyógyszeres ellátás mellett az ilyen típusú betegek pszichés vezetése is kiemelt jelentőségű, ezért a pulmonológusok, a családorvosok, a belgyógyászok közös összefogása hozhatja meg a sikeres gyógyulást.

Tompos Tamás $d r$. a fül-orr-gégészeti betegségekról tartott jól felépített előadást. Anatómiai ismeretek részletes megvilágításával ismertette az egyes korszerú fül-orrgégészeti mútéti technikákat, és külön kitért a tonsillectomiával és az adenotomiával kapcsolatos indikációk jelentős változásaira, a megelőző terápia fontosságára. Összefoglalásként kiemelte a fej-nyak sebészeti mútéti beavatkozások utáni folyamatos rehabilitációs tevékenység fontosságát, a meghatározott időközönkénti kontrollvizsgálatok szükségességét.

Knausz Márta dr. a légúti infekciókban az empirikus antibiotikum-választás lehetôségeit tárgyalta, és mondanivalóját alátámasztotta a helyi rezisztenciaviszonyokkal. Ismertette az otthon szerzett felső és alsó légúti infekciókban előforduló leggyakoribb kórokozókat, pneumoniák esetén a kórlefolyás súlyossága szerint. Előadásában kitért az aktuális légúti megbetegedésre, a szezonális influenza járványügyi helyzetére, az oltóanyagra, az antivirális terápia és profilaxis lehetőségére, illetve a másodlagos bakteriális fertőzésekre. A hallgatóság röviden betekinthetett a mikrobiológiai diagnosztikába, és végül egy öszszefoglalót hallhattak a területi ellátás során leginkább terápiás problémát okozó multirezisztens kórokozóról, az MRSA-ról, annak 3 különböző típusáról.

Muzsay Géza dr. a kötelező és ajánlott védőoltások szerepéről tartott összefoglaló előadást. A védőoltások az orvostudomány legkiemelkedőbb találmányai közé tartoznak, segítségükkel betegségek tûnhetnek el. Nagyon fontos, hogy a nálunk kiemelkedően magas átoltottság a kötelező védőoltásokkal kapcsolatban megmaradjon, mert az oltási fegyelem lazulása ismét járványokkal fenyegethet. Rendkívül értékes lehet a védőoltásokkal kapcsolatos kommunikáció, hiszen a tájékoztatás elmulasztása komoly következményekkel járhat. Az aktualitásokról, az indikációkról, kontraindikációkról, a szabályozás változásairól, új védőoltások megjelenéséről az évente megjelenő Epinfo-ból kaphatnak tájékoztatást a kollégák. Az előadó részletesen beszámolt a pneumococcus elleni védőoltás kötelezővé tételéről csecsemők számára, valamint a térítésmentes humán papillomavírus elleni kampányoltásról. Zárásként megemlítette, hogy újdonságként hazánkban is elérhető a B csoportú meningococcus elleni vakcina, amely elsősorban a csecsemóknek, kisdedeknek és serdülőknek ajánlható.

Sirák András dr. a sürgósségi betegellátás és elsősegélynyújtás korszerü ismereteiről számolt be. Nagy ívú előadásában - számos esetismertetést követően - a hallgatóságot interaktív módon bevonva, részletes gyakorlati bemutatót tartott a korszerű elsősegélynyújtás legfontosabb teendőiről. Kiemelte a defibrillátorkészülék hathatós szerepét, amelynek hosszabb távon, akár a laikus segítők kezében is, jelentős szerepe lehet a hirtelen légzésleállás miatti mortalitási ráta csökkentésében.

A rendezvény zárásaként az Alapellátási Szabadegyetem szakmai igazgatójának, Schmidt Péter professzornak előterjesztése alapján Borkai Zsolt, Győr város polgármestere elismerő oklevelet és értékes ajándékot adott át az elmúlt 25 év során legaktívabb részt vevő kollégáknak. A díjazottak: Szalai Mária dr. és Szijjártó István dr. sümegi, Hidas János dr. vértessomlói, Balogh 
Emil dr. csopaki, Tardos Károly $d r$. győri háziorvosok. Ugyancsak elismerésben részesült Schneider Károly dr., Osli, Veszkény és Öntésmajor nyugalmazott körzeti orvosa, valamint Gyarmathy László dr., a Budapesti Honvéd Kórház osztályvezetô fóorvosa, Decastello Alice dr., Budapest VII. kerületi oktató családorvos, felülvizsgáló fóorvos és Szabó Tibor dr. foglalkozás-egészségügyi szakorvos, az Országos Egészségbiztosítási Pénztár szombathelyi fóosztályvezetője.

A jubileumi továbbképzés jelentősen hozzájárult az egészségügyi alapellátás rang- jának és minőségi munkájának elismeréséhez, és hatékonyan szolgálta a családorvosok folyamatos képzését és továbbképzését.

Prof. dr. Schmidt Péter Dr. Knausz Márta

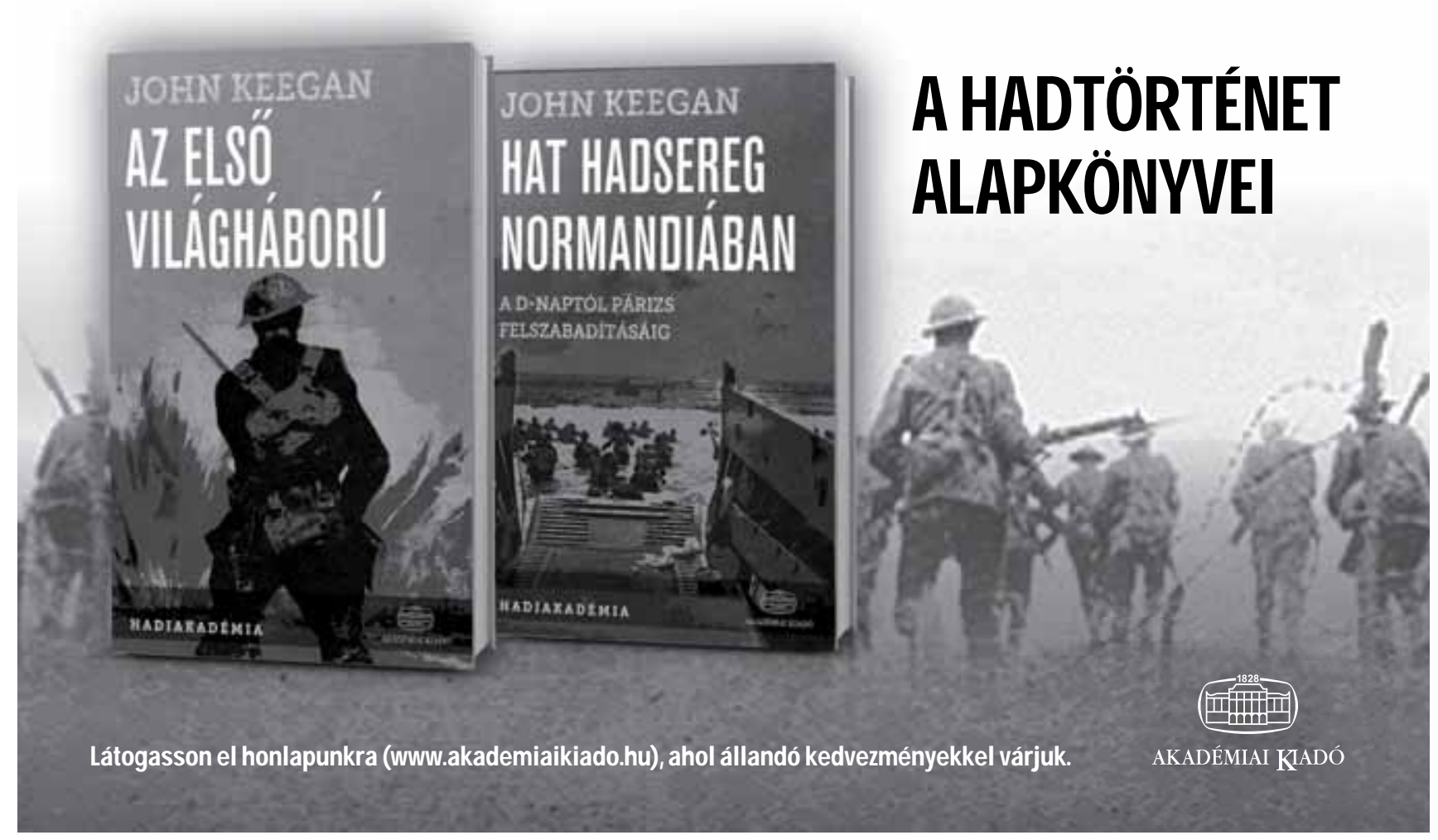




\section{Dick Swaab}

\section{Az agyunk mi vagyunk - $\mathrm{Az}$ anyaméhtől az Alzheimerig}

Libri Könyvkiaó, Budapest, 2014

Minden ember életében különösen fontos szerepet tölt be az emberi test központjaként számon tartott agy. Ez a szerv nemcsak azért kiemelt jelentőségü, mert irányítja és összehangolja az egész emberi szervezet múködését, önfenntartását és szabályozását, hanem mert otthont ad az ösztönöknek, vágyaknak, álmoknak, egyszóval mindannak, ami emberré tesz minket. Azonban, mint minden emberi szerv esetében, az agynak is számtalan hatása van olyan első ránézésre rejtett jelenségekre, mint a szexuális hovatartozás, az agresszivitás szintje vagy éppen a morális viselkedés különféle formái. Ezenfelül az agyat ért káros hatások befolyásolhatják akár az egész emberi élet hátralevő részét, sokszor szinte ellehetetlenítve azt. A jelen kötet azoknak az emberi agyban lezajló folyamatoknak, illetve az agy által gyakorolt hatásoknak az ismertetésére törekszik, amelyek bemutatják, hogyan gondolkodunk, küzdünk és szeretünk.

A szerző az agykutatás nemzetközileg elismert szakértője, az Amszterdami Egyetem professzora, aki harminc éven át vezette a Holland Nemzeti Agykutató Intézetet. Számos kutatási területe közül kiemelkedik az Alzheimer-kór, a depresszió, a nemi különbségek megnyilvánulásai, illetve az anyaméhben végbemenő biokémiai változásoknak az emberi agyfejlódésre gyakorolt hatása. Vizsgálatokat folytatott az étkezési rendellenességek, a sclerosis multiplex, illetve a Huntington-kór kapcsán is. 1985ben megszervezte a Holland Agybankot, amely számos agyszövetmintát gyújtött be, kezelt, illetve juttatott el számtalan kutatócsoporthoz, ezzel hozzájárulva az egyik legcsodálatosabb emberi szerv pontosabb megismeréséhez. Tanulmányai rendszeresen jelennek meg a Nature és a Science lapok hasábjain.

A könyv, noha szerzője eredetileg ismeretterjesztő múnek szánta, igen vaskos, ám ez a vaskosság inkább előnyt, semmint hátrányt jelent, hiszen szükséges a több száz oldalnyi terjedelem ahhoz, hogy témáját alaposan körbejárja és bemutassa. Az írás keretét egy utazás adja: a könyv lapjait lapozva megismerhetjük az emberi élet teljes folyamatát a fogantatás pillanatától egészen addig a percig, amíg az agyban végleg ki- alszanak a fények, és az egyén teljesen megszűnik létezni. A könyv előszavában - a tényleges utazás megkezdése előtt - Swaab hihetetlen optimizmusáról tesz tanúbizonyságot, amikor ismerteti a modern kor orvosi eljárásainak, illetve felfedezéseinek pozitív, gyógyító hatását az olyan betegségek, mint az AIDS, a Parkinson-kór vagy éppen a tartós vakság, illetve az enyhe fokú halláskárosodás esetén (24-26. o.). Emellett bemutatja az eddigi legismertebb hasonlatokat, amelyeket az agyra, illetve annak szerkezetére alkalmaztak az elmúlt évszázadokban: Descartes géphasonlatától Swaab saját felvetéséig, amely szerint az agy nem más, mint a Churchill által építetett II. világháborús bunker, amely számtalan életjelenséget hangol össze, mozgat, utasít, felügyel. Akármihez is hasonlítjuk azonban ezt az alig másfél kilós csodát, a lényege mindig megmarad: egyik arca már jól ismert, míg a másik még rejtett előttünk.

A könyvben az agykutatás számos témakörét megismerhetjük, mint például $a$ terhesség ideje alatt a magzatfejlödést kárositó tényezők (59-80. o.), az agy szexualitást szabályozó szerepe (81-118. o.), az agy és a tudat kapcsolata (193-216. o.), vagy éppen az agresszió (217-230. o.), az autizmus (231-241. o.), illetve a morális viselkedés kérdésköre (299-314. o.).

A szexualitás kapcsán Swaab foglalkozik a heteroszexualitás, a homoszexualitás, illetve a transzszexualitás, valamint az ilyen jellegü szexuális orientáció eredetével. Megállapítja, hogy ezek a fajta szexuális beállítódások egyáltalán nem vezethetôk vissza semmifajta szocializációs folyamat eredményére. Állítását nem pusztán humánetológiai, hanem etológiai példákkal is alátámasztja, amikor bemutatja a homoszexualitás jelenségét az állatvilágban, rámutatva arra, hogy ez a jelenség mekkora arányban fordul elő a különféle állatfajoknál, továbbá, hogy milyen célt szolgál. Bizonyítása során nem pusztán annak a lehetôségét veti el, hogy valaki nővé, illetve férfivá nevelhető pusztán azáltal, hogy gyermekként a választott nemnek megfelelően neveljük, hanem azt is, hogy a homoszexualitás az egyén saját szabad döntése lenne. Mint írja, ezek mind az agyban, illetve az anyaméhben bekövetkezett kizárólag biológiai eredetû változásoknak a következményei.

$\mathrm{Az}$ agresszió jelenségét vizsgálva Swaab rámutat arra az újszerú felismerésre, miszerint nem kizárólag az erőszakot bemutató filmek, játékok vagy könyvek tehetőek felelőssé azért, hogy a társadalom egyes tagjai vagy csoportjai erôszakosabbak másoknál
(1. Sáska, 2012). Noha jó néhány kutató (George Gerbner, Neil Postman, Vajda Zsuzsanna és Kósa Éva) korábban kimutatta az agresszió és az ilyen tartalmú források fogyasztása közötti kapcsolatot, Swaab más irányt ajánl fel a téma megismerése kapcsán. Leírása szerint ezek a tényezők ugyan nem elhanyagolhatóak az agresszív viselkedés kialakulásában, azonban közel sem játszanak olyan kritikus szerepet, mint azt korábban gondoltuk; helyette jóval nagyobb szerepet szán az agy prefrontális rétegének, illetve az amigdalának. Mint kiemeli, mindkettő stimulálása kiválthat megnövekedett agressziószintet, noha az utóbbi akár annak lecsökkenéséhez is vezethet (222-224. o.). Az agresszív viselkedés biológiai megalapozása után mindezeknek az állításoknak ellentmondani látszik Swaab későbbi kijelentése, miszerint „Az agresszió látványa agresszív viselkedést vált ki” (289. o.). Ez is bizonyítja azt, hogy noha az agresszió valóban biológiai eredetü jelenség mind az állatvilágban, mind az emberek között - mint ahogyan azt Csányi Vilmos is igazolta már jóval korábban (Csányi, 2006) -, mégis vannak olyan pszichés komponensei is a jelenségnek, amelyekkel számolni kell.

$\mathrm{Az}$ agy és a sport vonatkozásában elsőként a bokszolást szokás említeni. Swaab ezen sporton, illetve a K-1 esetein keresztül mutatja be, hogy ezek az elavult és sokak által sokszor barbár sportként számon tartott események pusztán a nép szórakoztatását, nagy összegek megszerzését szolgálják, illetve a tévékészülékek képernyőjén keresztül a nézők agressziószintjét növelik. Ez a gondolatmenet - noha nem teljesen megalapozatlan - talán kissé eltúlzott: nem feltétlenül kell ezeket a sportokat teljes mértékben számúzni a társadalomból, pusztán visszafejleszteni az önvédelem és a mozgás öröméért történő választható mozgásformák szintjére, szemben a profi sporttal. Swaab professzor a sportolás kapcsán egy kissé elnagyoltnak tünő kijelentést enged meg magának, amikor igen veszélyesként jellemzi a hobbifutást, akárcsak a kerékpározást. Megállapítása szerint ezek a mozgásformák jelentősen növelik az amyotrophiás lateralsclerosis (ALS) esélyeit, a test túlerőltetése, túlhajtása pedig egyenesen halálos, függetlenül attól, hogy „csak” kerékpározunk vagy éppen intenzív testépítést végzünk. Észrevétele és kutatásai alapján viszont bizonyos, hogy minél élénkebb szellemi életet él valaki, annál tovább élhet, ráadásul az aktív mentális tevékenységekkel átszőtt élet gátat vethet az Alzheimer-kór és az idôskori demencia kialakulásának, vagy csökkentheti azok mér- 
tékét. Szintén érdemes alaposan megfontolni a professzor üzenetének komolyságát a fejezet végét lezáró mondat kapcsán: „Ha pedig valaki sehogyan sem bírja ki sport nélkül, a legjobb, ha sakkozni kezd" (298. o.)

Számos ellentmondásosnak tünő állítás, erőteljes elfogultság és részrehajlás az emberi agynak az élet minden területére kiterjedő hatásáról, már-már egyfajta biológiai determinizmust felvonultató látomás jellemzi Swaab professzor úr írását. Óhatatlan, hogy a könyvben foglalt kijelentések nagy részét sokan visszautasítják: van, aki vallási, más lelkiismereti, esetleg szakmai okokból, esetleg pusztán dacból. Mégis, a gyakran sokkoló állítások remélhetóleg arra sarkallják majd az olvasót, hogy alaposabban utánanézzen bizonyos dolgoknak az agyával és annak hatásaival kapcsolat- ban, hogy jobban megismerje azt, mind a laikusok, mind a szakemberek szintjén. Ha pedig ez volt Swaab professzor célja, akkor vélhetőleg sikeresen elérte azt.

Kárpáti László Eszterházy Károly Főiskola, Eger Neveléstudomány Doktori Iskola

\section{A MAZSIHISZ Szeretetkórház (1145 Budapest XIV., Amerikai út 53-55.) orvos igazgatója álláspályázatot hirdet egy fö belgyógyász szakorvos, vagy közvetlenül szakvizsga előtt álló kolléga részére.}

Gerontológiai szakvizsga, vagy ilyen irányultságú munkatapasztalat, illetve érdeklődés előnyt jelent.

Nyugdijas szakorvos jelentkezését is várjuk, teljes munkaidős foglalkoztatásban.

A pályázatokat a fenti címre, Dr. Deutsch Zsuzsanna orvos igazgató nevére kérjük küldeni.

Telefon: (06-1) 251-9568 • E-mail: drdeutschzs@szeretetkorhaz.hu 